B. Yang \& Y. Liu, Int. J. Sus. Dev. Plann. Vol. 14, No. 4 (2019) 367-378

\title{
EVALUATION ON THE SUSTAINABILITY OF URBANIZATION PROCESS BASED ON BIOLOGICAL FOOTPRINT MODEL
}

\author{
BINGQING YANG \& YUE LIU \\ School of Computer and Information Engineering, Fuyang Teachers College, Fuyang, China.
}

\begin{abstract}
With the rapid development of science and technology and economy, the living standard of people has tended to be higher year by year, and the degree of urbanization in China has also became increasingly higher. But the extensive economic development mode has led to the problems such as environmental pollution, waste of resources and the expansion of population. Currently one of the problems faced by China is how to find a balance between human and nature and between ecology and economy to achieve sustainable development. In this study, the sustainability of urbanization in Anhui province was evaluated using the ecological footprint model. The ecological footprint model of 2011 was analyzed in details, and the ecological footprint models of $2004 \sim 2011$ were compared. The ecological footprint per capita and ecological carrying capacity were on the rise from 2004 to 2011, but there was a deficit, which increased every year. It is concluded that the use of local ecological resources in Anhui province from 2004 to 2011 has exceeded the capacity of the local environment, causing damages to the ecosystem, and the local urbanization has been in an unsustainable state and the development structure of urbanization in Anhui province is unreasonable, resulting in an increased pressure on the ecological environment and a long-term unsustainable state.
\end{abstract}

Keywords: dynamic analysis, ecological footprint, sustainable development, urbanization.

\section{INTRODUCTION}

Since the 21st century, the world has entered a period of rapid development; however it is at the expense of environmental damages. How to slow down or even restrain ecological deterioration and realize new sustainable development has become a problem faced by all countries. How to quantitatively assess the sustainable development of a region has become a key issue in the field of sustainable development [1]. The ecological footprint model used in this study measured the degree of sustainable development in a region by comparing the needs of economic development and ecological theoretical supply. It is widely used in the argument on the relationship between ecological resources and economic development [2]. Salvo [3] assessed Brazil with the input-output model and ecological footprint and found high ecological footprint value in the livestock and fossil based industries and subaverage ecological footprint value in the output industry. York [4] found that the economic development has threatened the sustainable development of the environment China, India, Japan and the United States by comparing the ecological footprint of those countries between 1962 and 2003. In China, $\mathrm{Gu}$ [5] analyzed the ecological footprint of urban agglomeration in the middle reaches of the Yangtze River and found that the local ecological deficit was serious. Liu et al. [6] evaluated 319 natural reserves in China with ecological footprint analysis, which provides a powerful reference for decisions on protection of natural reserves. Chen [7] studied the sustainability of ecological environment in Xinjing district, Taiwan with emergetic ecological footprint model and ecological safety assessment to ensure the balance between ecological protection and tourism development. Besides the sustainable development of a region, ecological footprint can also used to evaluate single project, for example, carbon emission. In the evaluation of carbon emission of Tianjin Polytechnic University, 
China with ecological footprint evaluation and life cycle assessment, Liu et al. [8] found that the low carbon emission in the university was sustainable and put forward some effective suggestions for the improvement of low-carbon campus. The sustainability of urbanization can be determined based on the analysis of consumption of natural resources and local land carrying capacity. In this study, firstly, the local consumption of natural resources in Anhui were calculated, then the local ecological carrying capacity was calculated based on the basic data recorded in Anhui Statistical Yearbook and China Energy Statistical Yearbook, the ecological surplus and loss value was obtained from the comparison between the consumption of natural resources and local ecological carrying capacity. Moreover the footprint, ecological carrying capacity and ecological surplus and loss of 2001-2008 were compared to determine the condition of local sustainable development.

\section{THEORY OF ECOLOGICAL FOOTPRINT}

Ecological footprint as a method which can quantitatively determine the condition of sustainable development of a region is also called ecological appropriation. Theory of ecological footprint provides a way to uniformly describe different natural resources [9]. It can determine whether a region develops in a sustainable way by quantifying ecological resources of different categories provided by the measured region and comparing it with the resource consumption involved in the measured region. Besides the state of sustainable development of a region, ecological footprint can also be used for evaluating single project, for example, the influence of carbon emission, agricultural production, festival activity and construction wastes in process of urbanization on ecological environment [10]. It can provide detailed and reliable data support for effective measures for protection of ecological environment. Ecological footprint also has shortcomings [11]. Firstly, the accuracy of theoretical model is associated to basic data, and selection of yield factor and equivalence factor will also affect errors of results. Secondly, the model is more inclined to the influence of ecological environment on sustainability regardless of the influence of technical progress on environment. To achieve accurate and objective determination of the condition of sustainable development in a region, other models which can measure aspects except ecology are needed. Though some scholars include air into the ecological footprint evaluation, for example, Legg et al. [12] and Ciers et al. [13] included air into the model of ecological footprint for analyzing the carbon emission in the process of air travel, it was ignored in this study as its influence was small in this study.

\subsection{Definition of ecological footprint and its computational formula}

Ecological footprint refers to the quantity of productive land and water resource needed for supporting population consumption and absorbing generates wastes. The degree of sustainable development in a region can be identified by calculating the ecological peak and valley values of the ecosystem needed to maintain the area. The measurable objectives include individuals, cities and towns and national units. Its expression of the model [14] is:

$$
E F=M \times e f=M \times \sum\left(r_{j} \times B_{i}\right)=M \times \sum r_{j} \times \frac{d_{i}}{q_{i}},
$$

where $E F$ refers to the sum of ecological footprint of the measured region, $M$ refers to the sum of population in the region, ef refers to the per capita ecological footprint of the measured region, $r_{j}$ refers to equivalence factor, $B_{i}$ refers to the size of per capita productive land of the $i$-th consumption item converted in a ratio, $d_{i}$ refers to the per capita consumption of the $i$-th 
consumption item, $q_{i}$ refers to the average productivity of the $i$-th consumption item, and $i$ and $j$ refer to the number of categories of consumption items and ecological productive land.

\subsection{Definition of ecological carrying capacity and its computational formula}

Ecological carrying capacity refers to the sum of the maximum ecological productive land that can be provided by a region on the premise of not damaging local ecological productivity and ensuring the complexity of local ecological function, i.e. the maximum ecological footprint. Ecological carrying capacity can explain whether local land resource can effectively used for supporting economical activities [15]. Its expression is

$$
E C=M \times e c=M \times \sum b_{j} \times r_{j} \times y_{j},
$$

where $E C$ stands for the sum of local ecological carrying capacity, $M$ stands for the sum of local population, $e c$ stands for per capita ecological carrying capacity, $b_{j}$ stands for the size of per capita ecological productive land, $R_{j}$ stands for equivalence factor, and $y_{j}$ stands for yield factor.

\subsection{Ecological surplus and deficit and its computational formula}

Whether the productive consumption of a region has exceeded the bearing capacity of the ecosystem can be determined by calculating the local ecological surplus or deficit.

$$
E=E C-E F,
$$

where $E$ stands for ecological surplus or deficit, $E C$ stands for the sum of local ecological carrying capacity, and $E F$ stands for the sum of ecological footprint of a region. If $E$ is a positive number, it indicates that the region has ecological surplus and that the utilization of resources in productive consumption activities is within the tolerance range of ecological environment; otherwise it indicates that the region has ecological deficit and that the demand of human activities for environment has exceeded the tolerance range and the local ecological development is unsustainable.

\section{EVALUATION ON THE SUSTAINABLE DEVELOPMENT OF ANHUI}

Anhui province which lies in the East China locates in the middle and lower reaches of Yangtze River and Huaihe River. The area under the jurisdiction of Anhui is 140.1 thousand square kilometers, and the area of land is 139.4 thousand square kilometers. Anhui has a variety of land forms, including plain, tableland, hill and mountain. Moreover locating in the transitional area of temperate zone and subtropical zone, it has obvious monsoon climate. Animal and plant resources are abundant in Anhui. By the end of 2012, there were 5,245 species of higher plants and 742 categories of vertebrates in the territory. Anhui has a variety of minerals. By the end of 2011, 158 kinds of mines have been discovered, of which coal, iron, and copper are the local advantageous minerals. There are 4.22 million hectares of arable land, 3.29 million hectares of forest land, 1.05 million hectares of water and 1.93 million hectares of land for construction. The land for construction use has a rapid growth rate, but a low utilization efficiency, indicating an outstanding conflict between demand and supply. Protection of ecological environment and economic construction require support of reliable data.

The local sustainable development of Anhui was determined based on ecological footprint, ecological carrying capacity and ecological surplus and deficit using ecological footprint model in dynamic and static aspects. 


\subsection{Assessment in static aspect}

Researchers drew different conclusions on the ecological footprint of Anhui. Moreover the amount of data used in ecological footprint model is large. Therefore a detailed analysis was made in this study taking the ecological footprint of Anhui in 2011 as an example. The ecological footprint of the other years was calculated in the same way, but the detailed process was not presented.

\subsubsection{Calculation of ecological footprint}

The demands for the areas of six categories of ecological productive land were calculated according to the basic data of 2011 in Anhui Statistical Yearbook [16] and China Energy Statistical Yearbook [17]. Then the average ecological footprint was calculated using the computational formula of ecological footprint model. The results are shown in Table 1.

Table 1 shows that the average equivalence area of Anhui in 2011, i.e. per capita ecological footprint was $2.240273 \mathrm{hm}^{2}$. The ratios of ecological footprint of different categories of lands to total ecological footprint suggested that fossil fuel land had the highest ecological footprint, followed by cultivated land, water area, forest land, grassland and building land. The per capita ecological footprint of fossil fuel was $1.483422 \mathrm{hm}^{2}(66.22 \%)$, suggesting the good industrial development; the per capita ecological footprint of cultivated land was 0.339481 $\mathrm{hm}^{2}(21.98 \%)$; the per capital ecological footprint of water area and forestland was similar, $0.128873 \mathrm{hm}^{2}(5.75 \%)$ and $0.125274 \mathrm{hm}^{2}(5.59 \%)$, respectively. The percentages of per capita ecological footprint of grassland and building land were $3.98 \%$ and $3.30 \%$, respectively.

\subsubsection{Calculation of ecological carrying capacity}

The key of calculating ecological carrying capacity is to obtain the per capita usable area of different categories of lands. Then the per capita carrying capacity could be calculated using the computational formula of ecological carrying capacity mentioned in the preceding text. But the ecological carrying capacity of the usable area was the result of subtracting $12 \%$ of ecological carrying capacity of biodiversity protection area from the per capita ecological carrying capacity. The results are shown in Table 2.

Table 2 demonstrated that the per capita ecological carrying capacity of Anhui in 2011 was $0.753405 \mathrm{hm}^{2}$, and the actual per capita usable ecological biological carrying capacity was

Table 1: The average ecological footprint of Anhui in 2011.

\begin{tabular}{lccccccc}
\hline $\begin{array}{l}\text { Category } \\
\text { of land }\end{array}$ & $\begin{array}{c}\text { Cultivated } \\
\text { land }\end{array}$ & Grassland & $\begin{array}{c}\text { Forest } \\
\text { land }\end{array}$ & $\begin{array}{c}\text { Water } \\
\text { area }\end{array}$ & $\begin{array}{c}\text { Fossil } \\
\text { fuel } \\
\text { land }\end{array}$ & $\begin{array}{c}\text { Building } \\
\text { land }\end{array}$ & Total \\
\hline $\begin{array}{l}\text { Equivalence } \\
\text { factor }\end{array}$ & 2.39 & 0.51 & 1.25 & 0.41 & 1.25 & 2.39 & \\
$\begin{array}{l}\text { Per capita } \\
\text { equivalence } \\
\text { area }\left(\mathrm{hm}^{2}\right)\end{array}$ & 0.339 & 0.089 & 0.125 & 0.129 & 1.483 & 0.074 & 2.240 \\
$\begin{array}{l}\text { Proportion } \\
(\%)\end{array}$ & 15.15 & 3.98 & 5.59 & 5.75 & 66.22 & 3.30 & 100 \\
\hline
\end{tabular}


Table 2: The biological carrying capacity of Anhui in 2011.

\begin{tabular}{|c|c|c|c|c|c|c|c|}
\hline $\begin{array}{l}\text { Category of } \\
\text { land }\end{array}$ & $\begin{array}{c}\text { Cultivated } \\
\text { land }\end{array}$ & Grassland & $\begin{array}{c}\text { Forest } \\
\text { land }\end{array}$ & $\begin{array}{c}\text { Water } \\
\text { area }\end{array}$ & $\begin{array}{c}\text { Carbon } \\
\text { sequestration } \\
\text { land }\end{array}$ & $\begin{array}{l}\text { Building } \\
\text { land }\end{array}$ & Total \\
\hline $\begin{array}{l}\text { Per capita } \\
\text { area/hm } / \mathrm{hm}^{2}\end{array}$ & 0.103 & 0.001 & 0.063 & 0.031 & 0.000 & 0.033 & 0.103 \\
\hline $\begin{array}{l}\text { Equivalence } \\
\text { factor }\end{array}$ & 2.39 & 0.51 & 1.25 & 0.41 & 1.25 & 2.39 & \\
\hline Yield factor & 1.91 & 1.24 & 1.53 & 0.85 & 0 & 1.91 & \\
\hline $\begin{array}{l}\text { Per capita } \\
\text { ecological } \\
\text { carrying } \\
\text { capacity } / \mathrm{hm}^{2}\end{array}$ & 0.469 & 0.001 & 0.121 & 0.011 & 0.000 & 0.152 & 0.753 \\
\hline $\begin{array}{l}\text { Per capita } \\
\text { ecological } \\
\text { carrying } \\
\text { capacity af- } \\
\text { ter subtract- } \\
\text { ing } 12 \% / \mathrm{hm}^{2}\end{array}$ & 0.413 & 0.001 & 0.106 & 0.009 & 0.000 & 0.134 & 0.663 \\
\hline
\end{tabular}

$0.662996 \mathrm{hm}^{2}$ after the land area, which was used for protecting biodiversity was subtracted. Carbon sequestration land is corresponding to fossil fuel land, which can absorb the generated carbon dioxide. But as carbon sequestration land was not reserved, the area of that kind of land was 0 . Among the other five kinds of lands, the per capita ecological carrying capacity of cultivated land was the largest, $0.468951 \mathrm{hm}^{2}$, indicating rich cultivated land resource in that region; building land ranked the second $\left(0.152015 \mathrm{hm}^{2}\right)$; forest land ranked the third $\left(0.120823 \mathrm{hm}^{2}\right)$; water area and grass land ranked at the bottom $\left(0.010784 \mathrm{hm}^{2}\right.$ and $\left.0.000832 \mathrm{hm}^{2}\right)$. The percentage of the per capita ecological carrying capacity was too low, reflecting scarcity of grass land.

\subsubsection{Calculation of ecological surplus and loss}

The per capita ecological surplus and loss of Anhui in 2011 could be obtained by comparing the aforementioned per capita ecological footprint and per capita ecological carrying capacity (Table 3).

Table 3 demonstrates that only the building land and cultivated land were surplus, and the four categories of lands had loss. Overall the per capita ecological footprint of Anhui was $2.240273 \mathrm{hm}^{2}$ in 2011, which was almost four times that of the per capita ecological carrying capacity $\left(0.662996 \mathrm{hm}^{2}\right)$; there was a loss of $1.577277 \mathrm{hm}^{2}$. It clearly revealed that the ecological footprint of Anhui greatly exceeded the local ecological carrying capacity in 2011 and the development of Anhui was so unsustainable and unsatisfactory that needs to be improved.

\subsection{Dynamic evaluation}

The dynamic analysis in this study focused on the comparison of the per capita ecological footprint and ecological carrying capacity. 
Table 3: The ecological surplus and loss of Anhui in 2011.

\begin{tabular}{lccccccc}
\hline $\begin{array}{l}\text { Category } \\
\text { of land }\end{array}$ & $\begin{array}{c}\text { Cultivated } \\
\text { land }\end{array}$ & Grassland & $\begin{array}{c}\text { Forest } \\
\text { land }\end{array}$ & $\begin{array}{c}\text { Water } \\
\text { area }\end{array}$ & $\begin{array}{c}\text { Fossil } \\
\text { fuel } \\
\text { land }\end{array}$ & $\begin{array}{c}\text { Building } \\
\text { land }\end{array}$ & Total \\
\hline $\begin{array}{l}\text { Per capita } \\
\text { ecological } \\
\text { carrying }\end{array}$ & 0.413 & 0.001 & 0.106 & 0.009 & 0.000 & 0.134 & 0.663 \\
capacity & & & & & & & \\
$\begin{array}{l}\text { Per capita } \\
\text { ecological } \\
\text { footprint }\end{array}$ & 0.339 & 0.089 & 0.125 & 0.129 & 1.483 & 0.074 & 2.240 \\
$\begin{array}{l}\text { Per capita } \\
\text { ecological } \\
\text { surplus and }\end{array}$ & 0.073 & -0.089 & -0.019 & -0.119 & -1.483 & 0.060 & -1.577 \\
loss & & & & & & & \\
\hline
\end{tabular}

\subsubsection{Ecological footprint of Anhui between 2004 and 2011}

The following results were obtained using the computational formula of ecological footprint and the basic data of 2004-2011 in Anhui Statistical Yearbook.

Table 4 and Fig. 1 demonstrate that the per capita ecological footprint of Anhui showed an upward trend from 2004 to 2011; it was $1.303576 \mathrm{hm}^{2}$ in 2004 and $2.240273 \mathrm{hm}^{2}$ in 2011 , showing an increase of about $71.9 \%$. The ecological footprint model can reflect the consumption of ecological resources in the analyzed area generally; the larger the number, the greater the consumption.

Table 4: The per capital ecological footprint of Anhui between 2004 and 2011.

\begin{tabular}{|c|c|c|c|c|c|c|c|c|}
\hline Year & 2004 & 2005 & 2006 & 2007 & 2008 & 2009 & 2010 & 2011 \\
\hline $\begin{array}{l}\text { Cultivated } \\
\text { land/hm² }\end{array}$ & 0.317 & 0.328 & 0.325 & 0.300 & 0.330 & 0.336 & 0.330 & 0.339 \\
\hline $\begin{array}{l}\text { Grassland/ } \\
\mathrm{hm}^{2}\end{array}$ & 0.033 & 0.056 & 0.065 & 0.064 & 0.069 & 0.074 & 0.083 & 0.089 \\
\hline $\begin{array}{l}\text { Forest } \\
\text { land/hm² }\end{array}$ & 0.064 & 0.072 & 0.087 & 0.088 & 0.096 & 0.094 & 0.119 & 0.125 \\
\hline $\begin{array}{l}\text { Water } \\
\text { area/hm² }\end{array}$ & 0.085 & 0.099 & 0.105 & 0.111 & 0.110 & 0.109 & 0.121 & 0.129 \\
\hline $\begin{array}{l}\text { Building } \\
\text { area/hm }{ }^{2}\end{array}$ & 0.057 & 0.064 & 0.062 & 0.048 & 0.064 & 0.075 & 0.074 & 0.074 \\
\hline $\begin{array}{l}\text { Fossil fuel } \\
\text { land/hm² }\end{array}$ & 0.747 & 0.835 & 0.894 & 0.997 & 1.139 & 1.256 & 1.369 & 1.483 \\
\hline Total $/ \mathrm{hm}^{2}$ & 1.304 & 1.455 & 1.538 & 1.608 & 1.808 & 1.944 & 2.095 & 2.240 \\
\hline
\end{tabular}




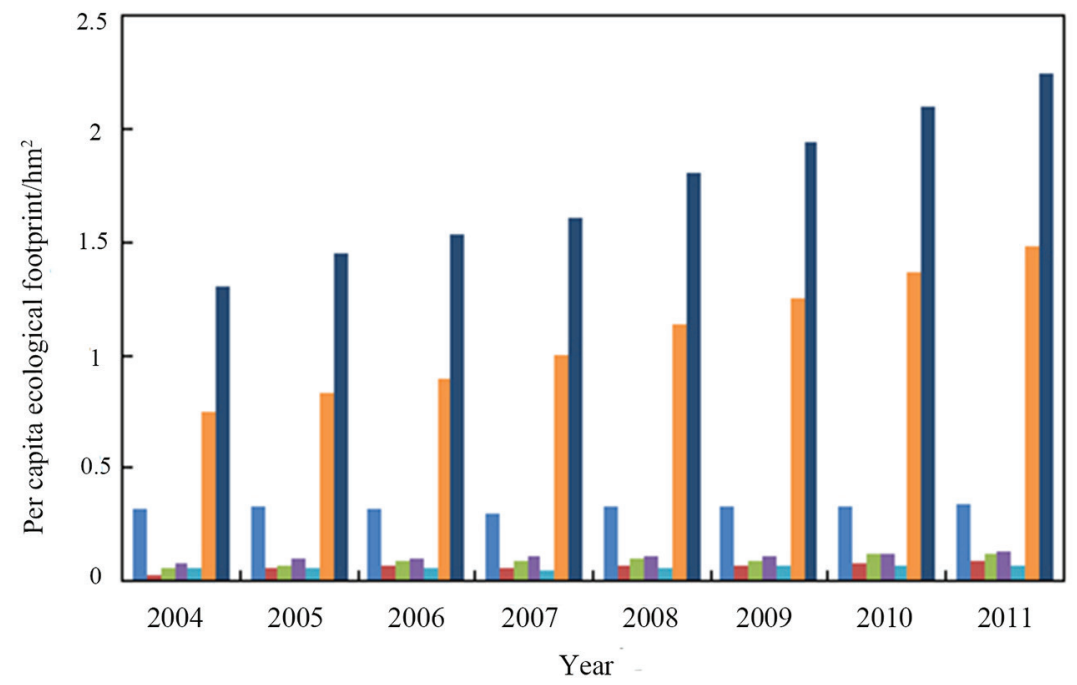

a Cultivated land $\mathbf{m}$ Grassland $\mathbf{m}$ Forest land $\mathbf{m}$ Water area $\mathbf{m}$ Building land $\mathbf{m}$ Fossil fuel land $\mathbf{\square}$ Total

Figure 1: The histogram of per capita ecological footprint of different categories of lands.

\subsubsection{The dynamic ecological carrying capacity of Anhui between 2004 and 2011}

The per capita ecological carrying capacity of Anhui between 2004 and 2011 was obtained using the computational formula of ecological footprint and the statistical data of 2004-2011.

As shown in Fig. 2, the per capita ecological carrying capacity of Anhui from 2004 to 2011 was on the rise, indicating that the local ecosystem was stable and that more and more

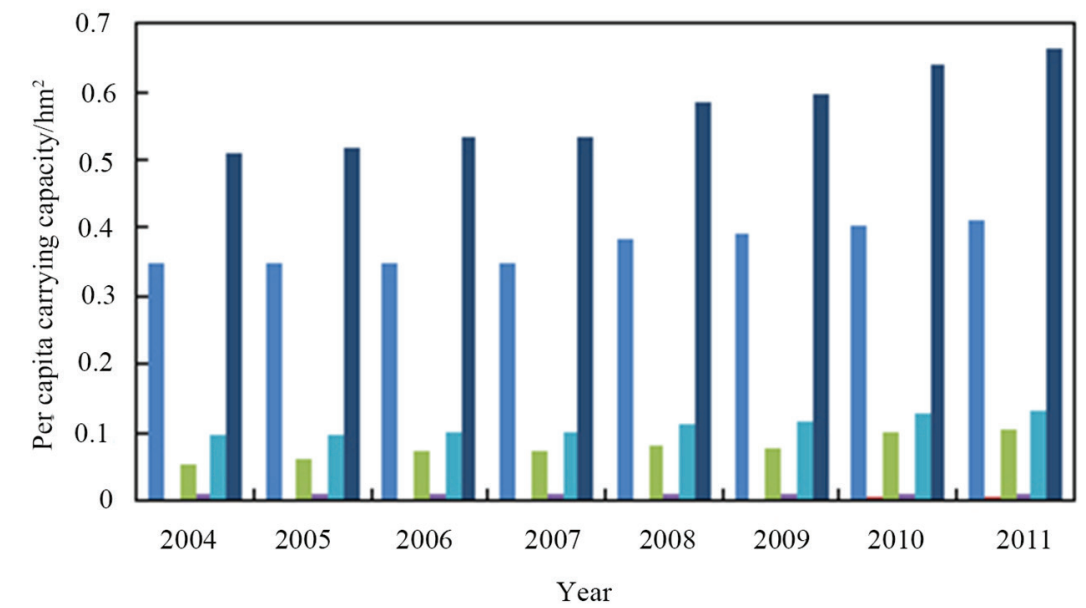

Cultivated land $\mathbf{a}$ Grass land Forest land $\mathbf{E}$ Water area

Total

Figure 2: The histogram of the per capita ecological carrying capacity of different categories of lands. 
Table 5: The per capita ecological carrying capacity of Anhui between 2004 and 2011.

\begin{tabular}{lcccccccc}
\hline Time & $\mathbf{2 0 0 4}$ & $\mathbf{2 0 0 5}$ & $\mathbf{2 0 0 6}$ & $\mathbf{2 0 0 7}$ & $\mathbf{2 0 0 8}$ & $\mathbf{2 0 0 9}$ & $\mathbf{2 0 1 0}$ & $\mathbf{2 0 1 1}$ \\
\hline $\begin{array}{l}\text { Cultivated } \\
\text { land } / \mathrm{hm}^{2}\end{array}$ & 0.349 & 0.348 & 0.349 & 0.348 & 0.383 & 0.391 & 0.403 & 0.413 \\
$\begin{array}{l}\text { Grassland/ } \\
\text { hm }^{2}\end{array}$ & 0.000 & 0.000 & 0.000 & 0.000 & 0.001 & 0.001 & 0.001 & 0.001 \\
$\begin{array}{l}\text { Forest } \\
\text { land/hm }\end{array}$ & 0.054 & 0.061 & 0.074 & 0.074 & 0.082 & 0.079 & 0.100 & 0.106 \\
$\begin{array}{l}\text { Water } \\
\text { area/hm }\end{array}$ & 0.009 & 0.009 & 0.009 & 0.009 & 0.010 & 0.009 & 0.010 & 0.009 \\
$\begin{array}{l}\text { Building } \\
\text { land/hm }\end{array}$ & 0.098 & 0.098 & 0.100 & 0.100 & 0.111 & 0.117 & 0.127 & 0.134 \\
$\begin{array}{l}\text { Carbon } \\
\text { sequestration }\end{array}$ & 0.000 & 0.000 & 0.000 & 0.000 & 0.000 & 0.000 & 0.000 & 0.000 \\
$\begin{array}{l}\text { land/hm } \\
\text { Total } / \mathrm{hm}^{2}\end{array}$ & 0.511 & 0.517 & 0.532 & 0.532 & 0.586 & 0.596 & 0.640 & 0.663 \\
\hline
\end{tabular}

resources could be provided by the ecological environment with the advancement of technologies. The per capita ecological carrying capacity of carbon sequestration land was 0 because no carbon sequestration land was reserved. The cultivated land, water area, grassland, forest land and building land showed a rising trend; the grassland remained unchanged, and the proportion was very low. The cultivated land was rising rapidly in 2007, and it had the largest proportion in the total per capita ecological carrying capacity, which was more than half; therefore it had the greatest contribution to the ecological carrying capacity. It revealed

Table 6: The dynamic ecological surplus and loss of Anhui between 2004 and 2011.

\begin{tabular}{|c|c|c|c|c|c|c|c|c|c|}
\hline Time & 2004 & 2005 & 2006 & 2007 & 2008 & 2009 & 2010 & 2011 & Average \\
\hline $\begin{array}{l}\text { Cultivated } \\
\text { land } / \mathrm{hm}^{2}\end{array}$ & 0.032 & -0.033 & -0.010 & -0.076 & 0.041 & -0.747 & -0.792 & 0.032 & -0.033 \\
\hline $\begin{array}{l}\text { Grass- } \\
\text { land/hm² }\end{array}$ & 0.020 & -0.056 & -0.012 & -0.090 & 0.034 & -0.835 & -0.939 & 0.020 & -0.056 \\
\hline $\begin{array}{l}\text { Forest } \\
\text { land/hm² }\end{array}$ & 0.024 & -0.065 & -0.014 & -0.095 & 0.038 & -0.894 & -1.006 & 0.024 & -0.065 \\
\hline $\begin{array}{l}\text { Water } \\
\text { area/hm² }\end{array}$ & 0.048 & -0.064 & -0.014 & -0.102 & 0.053 & -0.997 & -1.076 & 0.048 & -0.064 \\
\hline $\begin{array}{l}\text { Building } \\
\text { land/hm² }\end{array}$ & 0.053 & -0.068 & -0.015 & -0.100 & 0.047 & -1.139 & -1.222 & 0.053 & -0.068 \\
\hline $\begin{array}{l}\text { Fossil fuel } \\
\text { land/hm² }\end{array}$ & 0.055 & -0.074 & -0.015 & -0.099 & 0.042 & -1.256 & -1.348 & 0.055 & -0.074 \\
\hline Total/hm² & 0.072 & -0.082 & -0.019 & -0.111 & 0.053 & -1.369 & -1.455 & 0.072 & -0.082 \\
\hline
\end{tabular}


that the cultivated land resource was rich in Anhui and was the basic industry to develop economy. Building land ranked the second, and the amplitude of increase was large after 2007. Water area and grassland contributed less to the ecological carrying capacity of Anhui.

3.2.3 The dynamic ecological surplus and loss of Anhui between 2004 and 2011

In Fig. 3, the horizontal coordinate is year, and the vertical coordinate is the value of ecological surplus and loss (unit: $\mathrm{hm}^{2}$ ). Figure 3 shows that the per capita ecology of Anhui was in a state of deficit between 2004 and 2011, and the deficit increased year by year. The current situation suggested that the material demand of the local economic activities was far greater
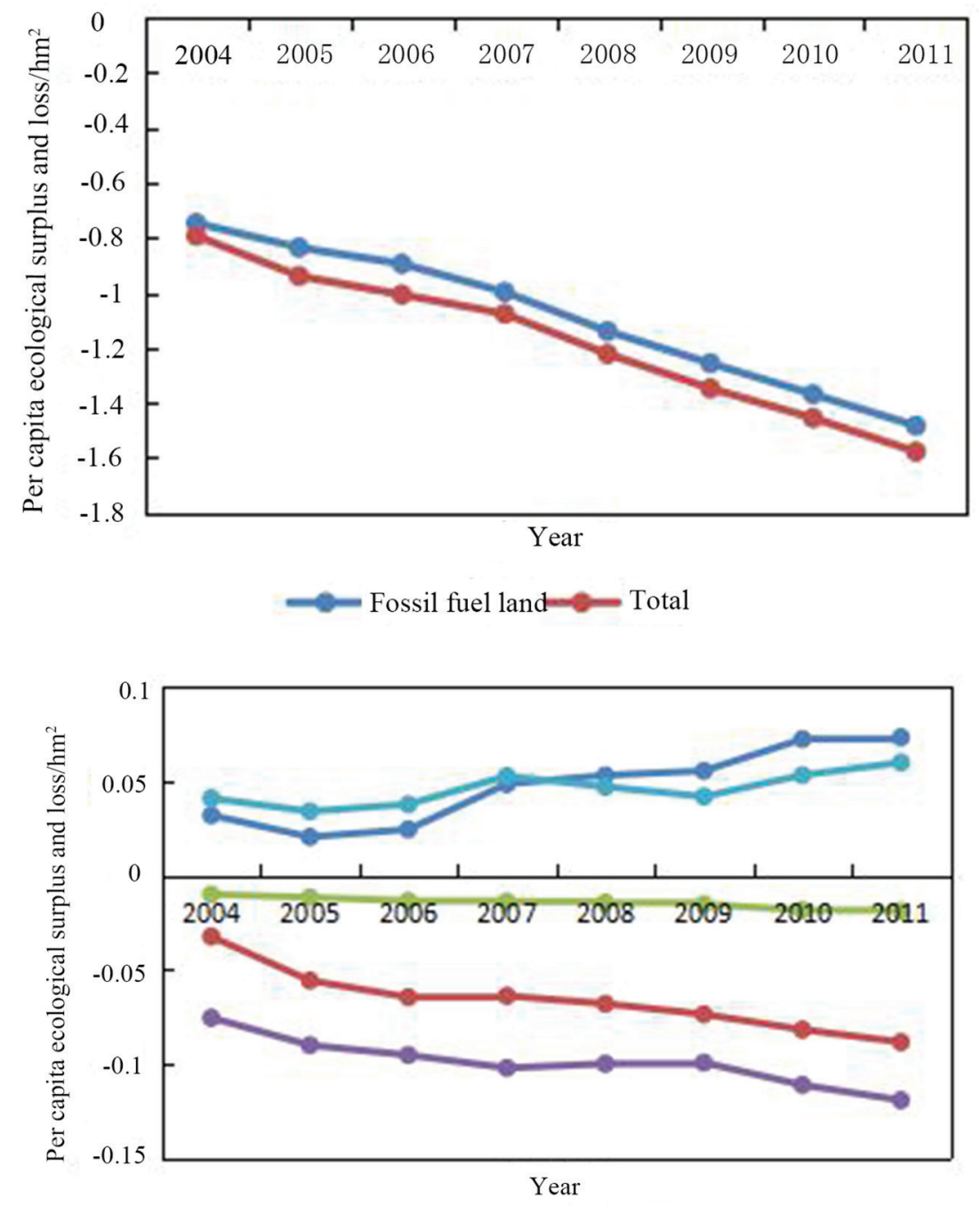

- Cultivated land - Grass land $\longrightarrow$ Forest land $\longrightarrow$ Water area - Building land

Figure 3: The line chart of the dynamic ecological surplus and loss of Anhui between 2004 and 2011. 
than the resources that the local ecology could provide, i.e. supply is less than demand, and the gap was growing. It could be noted that the consumption of natural resources was increasing with the development of economy, which has exceeded the degree that the ecology can provide, and the pressure on the natural environment also became more and more serious.

The average ecological deficit of Anhui between 2004 and 2011 was $1.176992 \mathrm{hm}^{2}$, among which the per capita deficit of energy consumption was the largest, $1.090115 \mathrm{hm}^{2}$; the secondary source of the deficit was the per capita deficit of water area $\left(0.099203 \mathrm{hm}^{2}\right)$, grassland $\left(0.066202 \mathrm{hm}^{2}\right)$ and forest land $\left(0.014615 \mathrm{hm}^{2}\right)$. Building land and cultivated land had surplus, but was not enough to thoroughly offset the deficit. Therefore, the keys of reducing the ecological deficit were controlling the ecological footprint of energy, strengthening the protection of forest and cultivated land and reducing the development of water area and grassland.

\section{DISCUSSION}

According to the results of static ecological footprint calculation in 2011 and dynamic ecological footprint calculation in 2004-2011, the per capita ecological footprint of Anhui province shows an upward trend, and the per capita ecological carrying capacity also shows an upward trend, but the ecological profit and loss has been in the deficit, with an increase every year and increased amplitude. The reasons for the increase of per capita ecological footprint are as follows: (1) with the development of economy, people's consumption capacity is also rising rapidly, and the demand for material is also increasing; (2) the demand for natural resources is increasing, and the impact on the ecological environment is also increasing. The proportion of fossil fuel land is increasing year by year, and the proportion of fossil fuel land is the largest, which is the main factor of the increase of ecological footprint.

The reason for the increase of per capita ecological carrying capacity is that the local ecosystem in Anhui province is relatively stable during this period, the development of technology makes the exploitation of resources more fully, and the cultivated land resources in Anhui province are rich, which is the basic industry for the development of economy. Construction land ranked second, and the increase increased after 2007.

Per capita ecological profit and loss depends on per capita ecological footprint and per capita ecological carrying capacity. Although per capita ecological footprint and per capita ecological carrying capacity are on the rise during 2004-2011, the per capita ecological profit and loss curve shows a loss on the whole. It was found from the ecological surplus and loss curves of different types of lands that fossil fuel land, which had the largest proportion increased considerably between 2004 and 2011, far exceeding the other types of lands. The reason was that the rapid development of the social economy was inseparable from the consumption of energy and carbon sequestration land, which was not reserved, was always in a state of deficit.

The deficits of grassland and water increased year by year, because the growing living standard of local residents produced more demands for livestock meat products and its by-products, but the area of grassland and water was decreasing.

Building land and cultivated land had surplus, which indicates that the building land and cultivated land could meet the development demand by the end of 2011. The reason for the surplus of the cultivated land was the land resource associated policy released in 2006. Moreover the strong support of the government for agriculture and the progress of agricultural technology promoted the improvement of production efficiency of cultivated land. Although building land was in the surplus state, it had a fluctuation, decrease first and then increase. It was because that the urbanization in Anhui was slow before 2005 and the transfer of industrial center of Yangtze River Delta region accelerated urbanization and increased the area of building land after 2005. 
Forest land was always in a state of deficit, but the value was low and the fluctuation was gentle. In spite of the increased demand for wood because of urbanization, the carrying capacity of forest land was improved because of the policy of convert cultivated land into forests released by the local government. In general, the forest land resources could basically maintain the local development.

\section{CONCLUSION}

The sustainable development of urbanization in Anhui was studied using ecological footprint model and the basic statistical data of ecological environment and energy consumption, especially in 2011. Moreover the sustainable development conditions of Anhui between 2004 and 2011 were compared.

The static analysis on the sustainable development of Anhui in 2011 suggested that the per capita ecological footprint, per capita ecological carrying capacity and ecological deficit were $2.240273 \mathrm{hm}^{2}, 0.662996 \mathrm{hm}^{2}$ and $1.577277 \mathrm{hm}^{2}$, respectively.

Whether the urbanization of Anhui was sustainable could be determined through the analysis on the footprint of Anhui between 2004 and 2011. The per capita ecological footprint of Anhui between 2004 and 2011 showed an increasing tendency, the per capita ecological carrying capacity showed a decreasing tendency, but there was a deficit which increased faster year by year.

\section{ACKNOWLEDGEMENT}

This study was supported by SK2015A723 and SK2016A0708.

\section{REFERENCES}

[1] Teixidó-Figueras, J. \& Duro, J.A., International ecological footprint inequality: A methodological review and some results. Environmental \& Resource Economics, 60(4), pp. 607-631, 2015. https://doi.org/10.1007/s10640-014-9784-X

[2] Galli, A., Giampietro, M., Goldfinger, S., Lazarus, E., Lin, D., Saltelli, A., Wackernagel, M. \& Müller, F., Questioning the ecological footprint. Ecological Indicators, 69, pp. 224-232, 2016. https://doi.org/10.1016/j.ecolind.2016.04.014

[3] Salvo, G., Simas, M.S., Pacca, S.A., Guilhoto, J.J.M., Tomas, A.R.G. \& Abramovay, R., Estimating the human appropriation of land in Brazil by means of an input-output economic model and ecological footprint analysis. Ecological Indicators, 53, pp. 78-94, 2015. https://doi.org/10.1016/j.ecolind.2015.01.027

[4] York, R., Rosa, E.A. \& Dietz, T., A tale of contrasting trends: Three measures of the ecological footprint in China, India, Japan, and the United States, 1961-2003. Journal of World-Systems Research, 15(2), pp. 134-146, 2015. https://doi.org/10.5195/ jwsr.2009.319

[5] Gu, Q., Wang, H., Zheng, Y., Zhu, J. \& Li, X., Ecological footprint analysis for urban agglomeration sustainability in the middle stream of the Yangtze River. Ecological Modelling, 318, pp. 86-99, 2015. https://doi.org/10.1016/j.ecolmodel.2015.07.022

[6] Liu, X., Jiang, D., Wang, Q., Liu, H., Li, J. \& Fu, Z., Evaluating the sustainability of nature reserves using an ecological footprint method: a case study in China. Sustainability, 8(12), p. 1272, 2016. https://doi.org/10.3390/su8121272

[7] Chen, H.S., Evaluation and analysis of eco-security in environmentally sensitive areas using an emergy ecological footprint. International Journal of Environmental Research Public Health, 14(2), p. 136, 2017. https://doi.org/10.3390/ijerph14020136 
[8] Liu, H., Wang, X., Yang, J., Zhou, X. \& Liu, Y., The ecological footprint evaluation of low carbon campuses based on life cycle assessment: A case study of Tianjin, China. Journal of Cleaner Production, p. 144, 2017. https://doi.org/10.1016/j.jclepro.2017.01.017

[9] Fu, W., Turner, J.C., Zhao, J. \& Du, G., Ecological footprint (EF): An expanded role in calculating resource productivity (RP) using China and the G20 member countries as examples. Ecological Indicators, 48, pp. 464-471, 2015. https://doi.org/10.1016/j. ecolind.2014.09.023

[10] Mancini, M.S., Galli, A., Niccolucci, V., Lin, D., Bastianoni, S., Wackernagel, M. \& Marchettini, N., Ecological footprint: Refining the carbon footprint calculation. Ecological Indicators, 61, pp. 390-403, 2016. https://doi.org/10.1016/j. ecolind.2015.09.040

[11] Galli, A., On the rationale and policy usefulness of ecological footprint accounting: The case of Morocco. Environmental Science \& Policy, 48, pp. 210-224, 2015. https://doi. org/10.1016/j.envsci.2015.01.008

[12] Legg, R., Moore, J., Kissinger, M. \& Rees, W., A Greenhouse gas emissions inventory and ecological footprint, analysis of metro vancouver residents' air travel. Environment and Pollution, 2(4), 2013. https://doi.org/10.5539/ep.v2n4p123

[13] Ciers, J., Mandic, A., Toth, L.D. \& Veld G.O., Carbon footprint of academic air travel: a case study in Switzerland. Sustainability, 11(1), p. 80, 2019. https://doi.org/10.3390/ su11010080

[14] Collins, A. \& Cooper, C., Measuring and managing the environmental impact of festivals: the contribution of the ecological footprint. Journal of Sustainable Tourism, 25(1), pp. 148-162, 2017. https://doi.org/10.1080/09669582.2016.1189922

[15] Qian, Y., Tang, L., Qiu, Q., Xu, T. \& Liao, J., A comparative analysis on assessment of land carrying capacity with ecological footprint analysis and index system method. Plos One, 10(6), p. e0130315, 2015. https://doi.org/10.1371/journal.pone.0130315

[16] Anhui Statistical Yearbook. China Statistics Press, 2012.

[17] China Energy Statistical Yearbook. China Statistics Press, 2012. 